\title{
Periorbital Cervicofascial Necrotising Fasciitis - A Case Series and A Literature Review
}

\author{
Gabriele Baniulyte $^{1, *}$, Ahad Shafi ${ }^{1}$, Rory MacIver ${ }^{2}$, Mark Ansell ${ }^{1}$ \\ ${ }^{1}$ Department of Oral and Maxillofacial Surgery, Queen Elizabeth University Hospital, Glasgow, Scotland \\ ${ }^{2}$ Department of Dentistry, Glasgow Dental Hospital and School, Glasgow, Scotland
}

Received October 27, 2019; Revised December 11, 2019; Accepted November 20, 2020

\section{Cite This Paper in the following Citation Styles}

(a): [1] Gabriele Baniulyte, Ahad Shafi, Rory MacIver, Mark Ansel, " Periorbital Cervicofascial Necrotising Fasciitis - A Case Series and A Literature Review," Open Journal of Dentistry and Oral Medicine, Vol. 8, No. 3, pp. 23 - 28, 2020. DOI: 10.13189/ojdom.2020.080301.

(b): Gabriele Baniulyte, Ahad Shafi, Rory MacIver, Mark Ansel (2020). Periorbital Cervicofascial Necrotising Fasciitis A Case Series and A Literature Review. Open Journal of Dentistry and Oral Medicine, 8(3), 23 - 28. DOI: 10.13189/ojdom.2020.080301.

Copyright $\bigcirc 2020$ by authors, all rights reserved. Authors agree that this article remains permanently open access under the terms of the Creative Commons Attribution License 4.0 International License

\begin{abstract}
Background: The aim of this report is to identify cases of cervicofascial necrotising fasciitis presenting to the Queen Elizabeth University Hospital Glasgow, over the course of 10 months. We reviewed and compared these cases to the literature in order to determine the optimal treatment provision. Methods: All patients admitted to our unit December 2017-October 2018 for cervicofascial necrotising fasciitis were identified. A retrospective data collection and analysis was carried out. Demographics, treatment provision and outcomes were examined for each patient. Results: A total of 5 patients were admitted to the Queen Elizabeth University Hospital for treatment of periorbital cervicofascial necrotising fasciitis in 10 months. All patients received urgent aggressive surgeries and empirical antibiotic therapies. All patients survived and went on to have facial reconstruction. Unfortunately, due to a delay in diagnosis, one patient required enucleation of their eye. Conclusions: Immediate surgical management as well as aggressive empirical antibiotic therapy remain the best treatment of cervicofascial necrotising fasciitis Timely diagnosis is of extreme importance to provide the best outcome for the patient. The Laboratory Risk Indicator for Necrotising Fasciitis score was utilised but did not produce consistently accurate results.
\end{abstract}

Keywords Necrotising, Fasciitis, Cervicofascial, Periorbital

\section{Introduction}

Necrotising Fasciitis (NF) is an acute, life-threatening and rapidly spreading infection of the fascia. Its prevalence has been estimated to be 3.5-4 cases per 100,000 people [1]. Of this, only $5 \%$ are NF relating to the head and neck region [1]. Periorbital necrotising fasciitis (PNF) has incidence of 0.24 cases per million per annum in the UK [2]. As only 200 cases have been published in the literature up to 2010 identifying cervicofacial necrotising fasciitis $(\mathrm{CNF})$, the diagnosis of this life-threatening disease is difficult [3]. In the US, King et al. [4] estimated that the incidence of the infection within the paediatric population is even less - 0.08 cases per 100,000 hospitalised children [4].

Incidence is thought to increase with age, as well as the presence of one or more chronic illnesses as over half the patients tend suffer from associated comorbidities [2,5]. Based on the literature review the mean age of a patient presenting with CNF was between 56-61 years old (with a range of 21-95 years) with the majority being male [2-9].

\section{Materials and Methods}

A retrospective analysis of patients who presented to Queen Elizabeth University Hospital (QEUH) December 2017-October 2018 with CNF was carried out. Their data and information was retrieved via 'Portal', the electronic patient records database for QEUH. Only patients with confirmed clinical and histopathological presentation 
were included.

\section{Results}

A total of five patients were identified meeting the criteria of NF December 2017- October 2018 (Table 1). All of these patients had periorbital CNF. Of particular interest was their presentation, as two patients were initially admitted to Ear Nose and Throat (ENT) ward for treatment of periorbital cellulitis prior to being referred to the Oral and Maxillofacial Surgery (OMFS) team.

Case 1 involved a 75 year old year old male who presented to local Accident and Emergency (A\&E) department with a 24 hour history of rapidly increasing swelling and erythema to left eye. The patient experienced "sticky discharge" from his left eye a day prior to admission and received an ointment from the pharmacist. He reported his left eye beginning to close completely that night and the swelling spreading across his face. On presentation we were unable to open the patient's left eye manually. Pus was discharging from lower lid with serous/pus-like discharge from behind the lids. No pain was reported on eye movements.

Case 2 was a 39 year old male who was admitted to ENT ward with left sided periorbital cellulitis. Patient reported recent viral throat infection and "sore throat" 1 week prior which settled. Overnight he developed facial swelling around the left eye. He was also feeling lethargic and was anorexic. On presentation his left eye was swollen shut with red sclera and active pus discharge.

Case 3 was a 62 year old male who was initially admitted to ENT ward with provisional diagnosis of left periorbital cellulitis. 4 days prior to the admission the patient was experiencing "flu-like" symptoms - cough, fever, malaise. He was complaining of a 48 hour history of swollen shut left eye and on the morning of the presentation his right eye was becoming swollen as well. On presentation his left eye was completely closed with crusty green/yellow discharge as well as right periorbital swelling.

Case 4 involved a 59 year old female who was admitted to ENT ward with left periorbital cellulitis. Patient reported a 1 week history of malaise, upper respiratory tract-like illness, "sore throat", blocked sinuses. Over the last 48 hours she started feeling increasingly unwell with pyrexia, nausea and vomiting. Over the last 24 hours increasing left periorbital swelling appeared with eye swollen shut and discharge present. On presentation patient's left eye was swollen shut with red sclera and purulent yellow discharge.
Case 5 was a 12 year old male who was admitted to QEUH with left eyebrow laceration and increasing swelling. A day prior to this he slipped on ice and fell, hitting his head on the ground and causing a laceration. He presented to $\mathrm{A} \& \mathrm{E}$ where the laceration was sutured by A\&E staff. As there was no loss of consciousness or vomiting, patient was discharged with no follow up. He represented to $\mathrm{A} \& \mathrm{E}$ the following day with increasing swelling and erythema over the left eye and 4 episodes of vomiting, left eye tenderness and purulent discharge. On presentation patient had proptosis of left eye, which was shut swollen with a tense orbit.

\subsection{Literature Review}

There is no consensus on the real trigger for necrotising fasciitis. A study has identified that 53\% of the cases included a precipitating event, which was: local trauma, recent local surgery, primary pharyngitis and conjunctivitis [2]. Some cases occurred as a complication after odontogenic/cervical infections of the fascia, or after cervical trauma [1]. However, NF has also been known to occur in cases with no recent local surgery or trauma [6].

Generally NF is associated with a low incidence but a high mortality and morbidity [1]. From the literature analysed, the published mortality rate varies between 3\% and $12.5 \%$, but can exceed $60 \%$ when NF presents with complications (descending necrotising mediastinitis and sepsis) $[1,2,5]$.Due to the severity and rapid spread of CNF, early diagnosis is essential $[6,7]$.

CNF can be caused by infections originating from sinus, peritonsillar region and salivary glands as well as dental infections (abscess, gingivitis, pulpitis, etc.) or infections secondary to surgery, trauma or, in rare cases, insect bites $[2,10]$. The main causative bacteria found was $\beta$-haemolyticStreptococcus A [2].

Initial signs and symptoms of CNF are often universally mild and can be misdiagnosed as erysipelas or cellulitis $[3,8,9]$. Patients can appear well and in minimal distress. Presentation can range from mild, localised cellulitis, to sore throat and fever, progressing to deep neck infections with subcutaneous emphysema and mediastinitis. A diagnosis of NF should be considered in the presence of additional signs and symptoms such as cutaneous anaesthesia, ill-defined areas of erythema and tenderness, dusky or grey skin discoloration, and crepitus [6]. Tissue necrosis may spread rapidly through superficial fascia and the subcutaneous fat layer, as well as through local nerves, arteries and veins [11].The bacterium closely related to NF is Streptococus pyogenes [2], which we have identified in all of the cases. 
Table 1. Summary of key points from the cases

\begin{tabular}{|c|c|c|c|c|c|c|c|c|c|c|c|}
\hline Case & $\begin{array}{c}\text { Age } \\
\text { (years) }\end{array}$ & Gender & $\begin{array}{c}\text { Initial } \\
\text { Presentation } \\
\text { Area } \\
\end{array}$ & Cause & $\begin{array}{l}\text { LRINEC } \\
\text { score }^{1}\end{array}$ & $\begin{array}{c}\text { WCC } \\
\left(\times 10^{9} / L\right)^{2}\end{array}$ & $\begin{array}{c}\mathbf{C R P} \\
(\mathbf{m g} / \mathbf{L})^{3}\end{array}$ & $\begin{array}{l}\text { Initial antibiotic } \\
\text { regime }\end{array}$ & $\begin{array}{c}\text { Total } \\
\text { number of } \\
\text { surgeries }\end{array}$ & Bacterium & $\begin{array}{c}\text { Hospital } \\
\text { Stay (days) }\end{array}$ \\
\hline 1. & 75 & Male & $\begin{array}{c}\text { Left Periorbital } \\
\text { Area }\end{array}$ & $\begin{array}{c}\text { Multiple } \\
\text { comorbidities/ } \\
\text { medical conditions }\end{array}$ & 8 & 28.8 & 274 & $\begin{array}{l}\text { meropenem, } \\
\text { gentamycin, } \\
\text { vancomycin, } \\
\text { flucloxicillin, } \\
\text { metronidazole, } \\
\text { ceftriaxone, } \\
\text { clindamycin }\end{array}$ & 5 & $\begin{array}{c}\text { Streptococcus } \\
\text { pyogenes }\end{array}$ & 25 \\
\hline 2. & 39 & Male & $\begin{array}{c}\text { Left Periorbital } \\
\text { Area }\end{array}$ & Unknown & 2 & 43.3 & 103 & $\begin{array}{l}\text { ceftriaxone, } \\
\text { gentamycin, } \\
\text { metronidazole, } \\
\text { clindamycin, } \\
\text { flucloxacillin, } \\
\text { benzylpenicillin }\end{array}$ & 5 & $\begin{array}{c}\text { Streptococcus } \\
\text { pyogenes }\end{array}$ & 11 \\
\hline 3. & 62 & Male & $\begin{array}{c}\text { Left Periorbital } \\
\text { Area }\end{array}$ & $\begin{array}{c}\text { Multiple } \\
\text { comorbidities/ } \\
\text { medical conditions }\end{array}$ & 9 & 21.6 & 377 & $\begin{array}{l}\text { clindamycin, } \\
\text { benzylpenicillin, } \\
\text { metronidazole, } \\
\text { gentamycin, } \\
\text { flucloxacillin }\end{array}$ & 5 & $\begin{array}{c}\text { Streptococcus } \\
\text { pyogenes, } \\
\text { Staphylococcus } \\
\text { epidermidis, } \\
\text { Micrococcus luteus, } \\
\text { Escherichia coli, } \\
\text { Staphylococcus } \\
\text { aureus } \\
\end{array}$ & 41 \\
\hline 4. & 59 & Female & $\begin{array}{c}\text { Left Periorbital } \\
\text { Area }\end{array}$ & $\begin{array}{c}\text { Multiple } \\
\text { comorbidities/ } \\
\text { medical conditions }\end{array}$ & 8 & 39.9 & 183 & $\begin{array}{l}\text { ceftriaxone, } \\
\text { gentamycin, } \\
\text { metronidazole, } \\
\text { clindamycin, } \\
\text { benzylpenicillin }\end{array}$ & 4 & $\begin{array}{c}\text { Streptococcus } \\
\text { pyogenes }\end{array}$ & 18 \\
\hline 5. & 12 & Male & $\begin{array}{l}\text { Left periorbital } \\
\text { area }\end{array}$ & Trauma to the area & 2 & 46.2 & 28 & $\begin{array}{l}\text { ceftriaxone, } \\
\text { clindamycin, } \\
\text { gentamycin, } \\
\text { flucloxicillin, } \\
\text { metronidazole, } \\
\text { cefotaxime }\end{array}$ & 5 & $\begin{array}{c}\text { Streptococcus } \\
\text { pyogenes }\end{array}$ & 10 \\
\hline
\end{tabular}




\subsection{The Laboratory Risk Indicator for Necrotising Fasciitis}

The Laboratory Risk Indicator for Necrotising Fasciitis (LRINEC) score was first described in 2004 [12,13]. It was introduced as a tool for detecting early cases of NF in patients with other severe soft tissue infections $[14,15]$. However, the authors understood that on its own, the LRINEC score is often unreliable, so advised that it be used in conjunction with clinical judgement due to the limited data available [7].Furthermore, in patients with multiple comorbidities, the inflammatory response may be muted, and caution is advised when interpreting the score in this type of patient [7].

Even when necrotising fasciitis is not initially considered, prompt surgical exploration under general anaesthesia should lead to an intra-operative diagnosis of necrotising fasciitis [6]. Early CT findings may show small fluid changes, thickening of the fascia or low-density changes in soft tissue consistent with early necrosis [6]. Microbiological samples should also be taken and cultured to aid diagnosis [6].

Another test used to help diagnose NF involves an incision into the affected area [6]. In patients with negative imaging, but diffuse cellulitis, continual fever/pain or symptoms and signs that are slow to improve, an incisional biopsy should be considered. Indicators highly suspicious of NF include limited bleeding or production of "dishwater-coloured fluids" [6]. As well as microbiological samples, histopathological samples should be taken, frozen and then analysed. Findings of obliterative vasculitis and soft tissue necrosis are characteristic of necrotising fasciitis [6].

\section{Discussion}

The QEUH serves approximately $41 \%$ of Scottish population. It contains the largest OMFS unit in Scotland and patients receive input from multiple specialities including ENT, anaesthetics, intensive care and microbiology. Our protocol indicates that pre-septal periorbital cellulitis should be admitted to the ENT ward for empirical IV antibiotic therapy, but currently there is no guidance on how to avoid misinterpreting periorbital CNF for periorbital cellulitis.

The patients in QEUH were ultimately diagnosed with CNF due to: clinical signs; WCC of above $11.0 \times 10^{9} / \mathrm{L}$; results of $\mathrm{CT}$ scan when already available, intraoperative clinical identification of necrotic tissue which was confirmed by histopathology and microbiology specimens. Table 1 also shows that all of our specimens came back positive for Streptococcus pyogenes bacterium, which has been linked with NF [2]. LRINEC score was used to confirm the suspicion of NF; however, ultimately the confirmation of definitive diagnosis was achieved during surgical debridement.
As can be identified from Table 1, the majority of the cases discussed in this paper were believed to have been caused due to multiple comorbidities (immunocompromising medical conditions). Early correct diagnosis is of vital importance to improve the future outcome [7]. Unfortunately, 3 out of 5 cases discussed were initially misdiagnosed as periorbital cellulitis therefore wasting time before the initial aggressive surgery was performed. Sadly, one patient required to have orbital enucleation due to the delay in treatment.

\subsection{Treatment}

Current gold standard treatment involves aggressive early intravenous antibiotic management (penicillin and clindamycin are the favoured consensus) in combination with early ( $<48$ hours) surgical debridement [12,16-18]. Commonly patients require multiple (2-5) surgical debridements [19]. Many publications describe an increase in mortality rate if there is a failure to perform early surgical debridement $[20,21]$.

Our patients received aggressive IV antibiotic regimen involving 5-7 different types of antibiotics; the antibiotics administered initially in all cases were gentamycin, metronidazole and clindamycin.

Interestingly, all of our patients suffered from NF originating from left periorbital area, with the vast majority of patients being male and an average age of 49 (range 12-75). Most of the patients underwent 5 surgeries in total (apart from one patient) with the last one being reconstructive and the first few being debridement. This confirms the previous literature suggestions [19].The average hospital stay was 21 days (range 10-41); the average WCC was 35.9 (range 21.6-46.2) and the average CRP was 193 (range 28-377). No direct link was found between the cases to explain this unusual increase in CNF diagnosis.

\section{Conclusions}

Necrotising Fasciitis is an extremely aggressive infection. Without early correct diagnosis and appropriate surgical and antibiotic management it will spread rapidly and can be fatal. The initial treatment should include aggressive surgical debridement, empirical intravenous antibiotic therapy and supportive therapies in Intensive Care Unit. 5 cases were identified in 10 months in Queen Elizabeth University Hospital, Glasgow, which covers an average of 2.173 million population. The authors note that there has not been any previous literature to show Necrotising Fasciitis rates in Scotland for comparison.

Therefore the authors suggest that Necrotising Fasciitis should be considered as part of our differential diagnoses more often to ensure timely surgical and antibiotic treatment is provided. This will prevent misdiagnoses and disease progression which in turn will improve patient outcomes and reduce morbidity and mortality rates. 


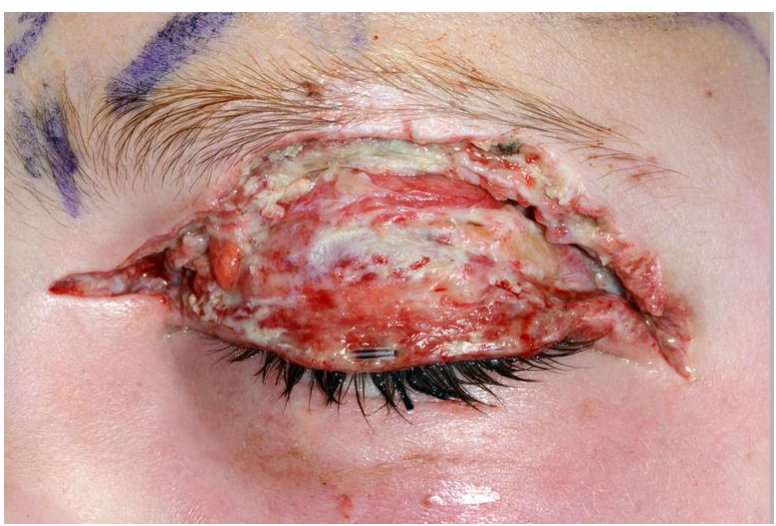

Figure 1. Case 5 during initial surgery. Published with the parent's consent.

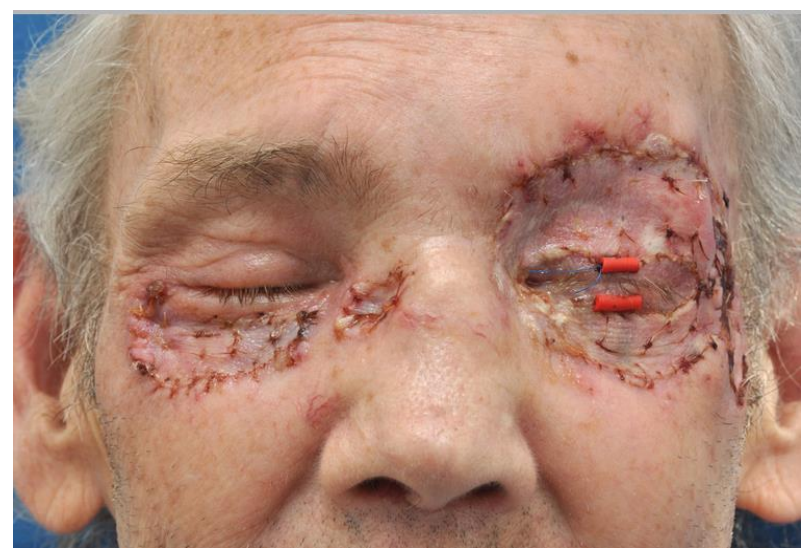

Figure 2. Case 3 after reconstruction with skin graft harvested from thigh. This patient's NF originated from the left hand side but spread to the right hand side by the time OMFS team was involved. Published with the patient's consent.

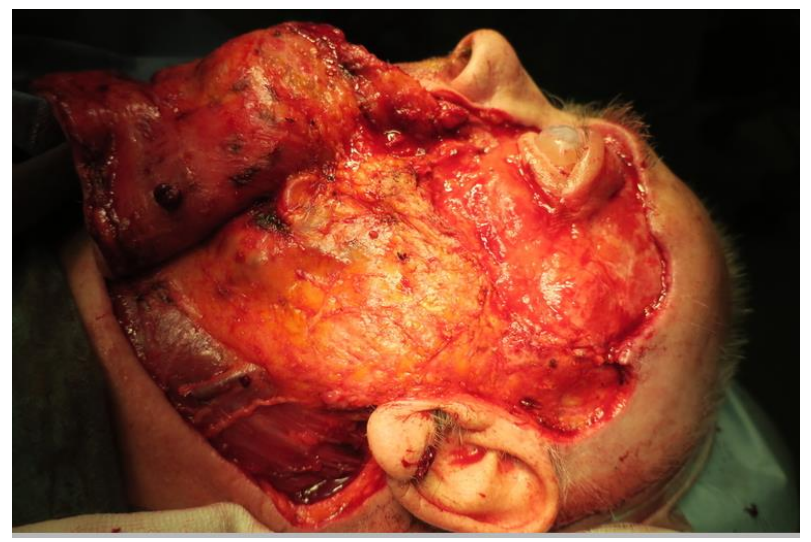

Figure 3. Case 1 during reconstruction with a cervicofacial rotation flap and a para-median forehead flap .Published with the patient's consent.

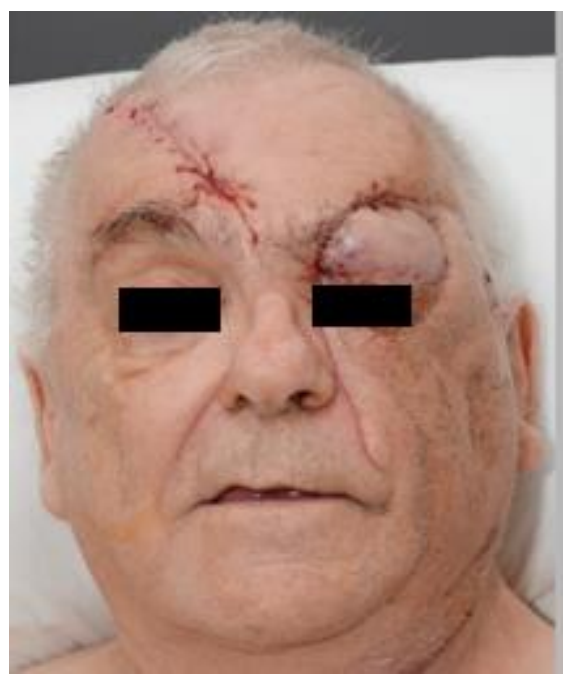

Figure 4. Case 1 after reconstruction with a cervicofacial rotation flap and a para-median forehead flap. Published with the patient's consent.

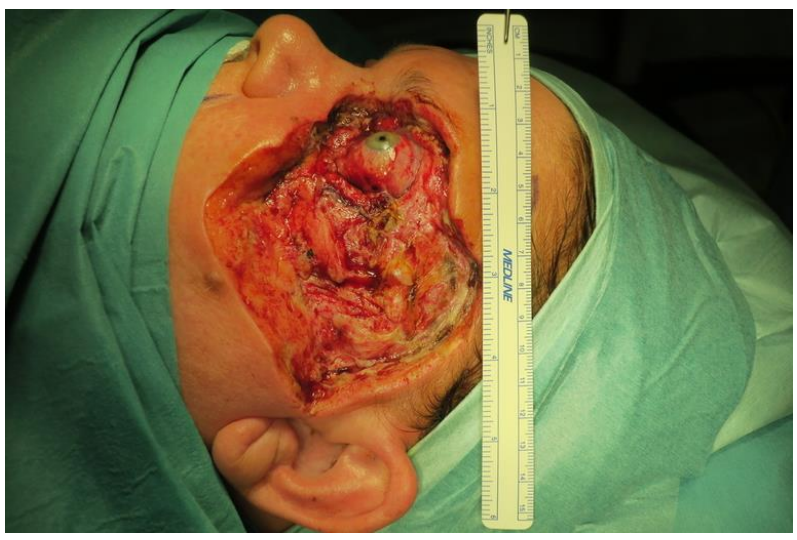

Figure 5. Case 4 during initial surgery. Published with the patient's consent.

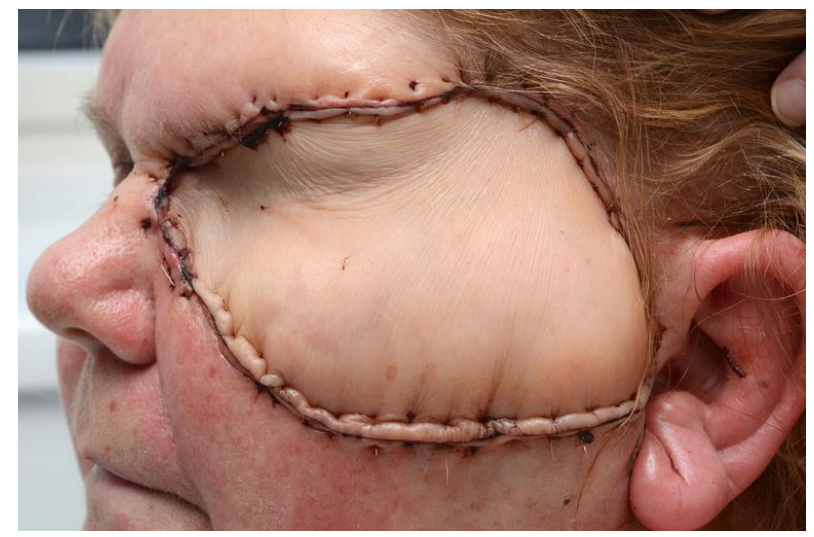

Figure 6. Case 4 after reconstruction with left radial forearm free flap. Published with the patient's consent. 


\section{Acknowledgements}

The authors are grateful for the support received from the Maxillofacial Staff at the Queen Elizabeth University Hospital, Glasgow.

\section{REFERENCES}

[1] Sandner A, Moritz S, Unverzagt S, Plontke SK, Metz D. Cervical Necrotizing Fasciitis-The Value of the Laboratory Risk Indicator for Necrotizing Fasciitis Score as an Indicative Parameter. J Oral MaxillofacSurg 2015: 73(12): 2319-33.

[2] Flavahan PW, Cauchi P, Gregory ME, Foot B, Drummond SR. Incidence of periorbital necrotising fasciitis in the UK population: a BOSU study. Br J Ophthalmol 2014;0:1-4. [doi:10.1136/bjophthalmol-2013-304735]

[3] Lee JW, Immerman SB, Morris LG. Techniques for early diagnosis and management of cervicofacial necrotising fasciitis. J LaryngolOtol 2010: 124(7): 759-64.

[4] King E, Chun R, Sulman C. Pediatriccervicofacial necrotising fasciitis: a case report and review of a 10-year national pediatric database. Arch Otolaryngol Head Neck Surg 2012: 138 (4):372-5. [doi: 10.1001/archoto.2012.119]

[5] Rajak SN, Figueira EC, Haridas AS, Satchi K, Uddin JM et al. Periocular necrotising fasciitis: a multicentre case series. Br J Ophthalmol 2016: 100(11): 1517-1520. [doi: 10.1136/bjophthalmol-2015-307445]

[6] Tan JH, Koh BT, Hong CC, Lim SH, Liang S et al. A comparison of necrotising fasciitis in diabetics and non-diabetics: a review of 127 patients. Bone Joint Journal 2016: 98-B(11): 1563-1568.

[7] Malik V, Gadepalli C, Agrawal S, Inkster C, Lobo C. An algorithm for early diagnosis of cervicofacial necrotising fasciitis.Eur Arch Otorhinolaryngol 2010: 267(8): p. 1169-77. [doi: 10.1007/s00405-010-1248-5].

[8] Lambade PN, Dolas RS, Virani N, Lambadi DP. Cervicofacial Necrotising Fasciitis of Odontogenic Origin: A Review. J Scientific Reports 2012: 1(8): 414. [doi:10.4172/scientificreports.414]

[9] Elliott DC, Kufera JA, Myers RAM. Necrotizing soft tissue infections: Risk factors for mortality and strategies for management. Ann Surg 1996: 224(5): 672-683.

[10] Jain S, Nagpure PS, Singh R, Garg D. Minor trauma triggering cervicofacial necrotizing fasciitis from odontogenic abscess. J Emerg Trauma Shock 2008: 1(2): 114-118.[ doi: 10.4103/0974-2700.43197]

[11] Wolf H, Rusan M, Lambertsen K, Ovesen T. Necrotising fasciitis of the head and neck. J Head Neck 2010:32(12): 1592-6. [doi 10.1002/hed December 2010]

[12] Wong CH, Khin LW, Heng KS, Tan KC, Low CO. The LRINEC (Laboratory Risk Indicator for Necrotizing Fasciitis) score: a tool for distinguishing necrotizing fasciitis from other soft tissue infections. Crit Care Med 2004: 32(7): p. 1535-41.

[13] Bechar J, Sepehripour S, Hardwicke J, Filobbos G. Laboratory risk indicator for necrotising fasciitis (LRINEC) score for the assessment of early necrotising fasciitis: a systematic review of the literature. Ann R CollSurgEngl 2017: 99(5): p. 341-346. [doi: 10.1308/rcsann.2017.0053]

[14] Swain RA, Hatcher JC, Azadian BS, Soni N, De Souza B. A five-year review of necrotising fasciitis in a tertiary referral unit. Ann R CollSurgEngl 2013: 95: 57-60. [doi 10.1308/003588413X13511609956093]

[15] Neeki MM, Dong F, Au C, Toy J, Khoshab N et al. Evaluating the Laboratory Risk Indicator to Differentiate Cellulitis from Necrotizing Fasciitis in the Emergency Department. West J Emerg Med 2017: 18 (4): 684-689. [doi:10.5811/westjem.2017.3.33607]

[16] Wong CH, Khin LW. Clinical relevance of the LRINEC (Laboratory Risk Indicator for Necrotizing Fasciitis) score for assessment of early necrotizing fasciitis. Crit Care Med 2005: 33(7): 1677.

[17] Bhatt YM, Small M. Cervical necrotising fasciitis with descending necrotising mediastinitis.Postgrad Med J 2011:87(1030):570.

[18] Maqbool M, Ahmad R, Ahmed R, Qazi S. Necrotising fasciitis in the head and neck region. Br J Plast Surg 1992:45(6): 481-3.

[19] Chunduri NS, Madasu K, Tammannavar PS, Pushpalatha C. Necrotising fasciitis of odontogenic origin. BMJ Case Rep 2013. [doi: 10.1136/bcr-2012-008506]

[20] Muhammad JK, Almadani H, Al Hashemi BA, Liagat M. The value of early intervention and a multidisciplinary approach in the management of necrotizing fasciitis of the neck and anterior mediastinum of odontogenic origin. J Oral Maxillofac Surg 2015: 73(5): 918-27. [doi: 10.1016/j.joms.2014.12.021]

[21] Charadva H, Chiu GA, Yanev N. Infraorbital necrotising fasciitis: importance of rehabilitation in vulnerable patients. Br J Oral Maxillofac Surg 2016: 54(8): 970-971. 